\title{
現代日本の独立住宅にみられる架構によるモデュールに関する研究 STUDY ON THE MODULE OF FRAMEWORK IN JAPANESE CONTEMPORARY HOUSES
}

\author{
竹内宏俊*, 岩岡 竜夫** \\ Hirotoshi TAKEUCHI and Tatsuo IWAOKA
}

\begin{abstract}
In this paper we clarified characteristics of relationship between spatial scales and frameworks of Japanese contemporary houses in terms of frame elements and module.

Initially, we analyzed their arrangements of beams and columns, and found several framework shapes.

Secondly, we analyzed their material, span and numbers of framework.

Thirdly, we analyzed their unit spaces, materials and cross-sectional shapes of column, and found several characteristics of sizes and proportions.

In conclusion, we pointed out that most of units spaces were articulated according to proportion and each size of framework, and that indicates spatial scales based on relationship between proportion and module of framework.
\end{abstract}

Keywords : module, proportion, framework, contemporary houses モデュール、プロポーション、架構、現代独立住宅

\section{1. 序}

\section{1-1. 研究の背景と目的}

商品化された規格化住宅などにおいては、単一のフレームを均等 に反復させることで建物が構成されているものがみられるが、これ らは住宅需要の拡大に対し、建設材料を規格化し標準化することで低 コストの量産供給を図ることが背景として挙げられる。現代の住宅 作品においては、そうした均等に配された架構 ${ }^{1)}$ 部材を、単に低コ ストを目的とすることのみに限らず、建設の施工過程や、部品の構 成やしくみをデザインとして露出させるような、いわばテクトニッ ク (結構的) 2) な表現として使用する作品も数多くみられる。均質 的な架構部材が内外に露出しているこうした住宅作品では、連続す る架構のフレームが構造体として機能するだけでなく、内部の間取 りやファサードといった、空間のスケールや形態的特徴を決定づけ るような、まさに建物全体の「枠組み」になっているといえる。こ うしたことから、建築家による住宅作品の架構によるモデュール 3)が、 実体としてどのように設定されているかを明らかにすることは、設 計の諸条件への対応や建築に扔ける表現の問題を捉える上で有効で あると考えられる。そこで本研究では、複数の異なる建築家による 住宅作品を対象として、架構の部材やスパンなどの寸法（以下架構 寸法）と、架構によるモデュールにみられる特徴との関係によって
成立する建築の空間スケールや形態的特徴の一端を明らかにするこ とを目的とする。

\section{1-2. 既往の研究および本研究の意義}

これまでなされてきた住宅のモデュールや架構に関する研究のう ち、本研究のように複数の異なる建築家による作品を対象とするも のは、架構と空間構成の相互関係からヴォリュームの分節による建 築の構成形式について検討したものがあるが 4)、5)、その他は特定の 建築家による住宅作品や国内外の特定の地域の現代的 - 伝統的な住

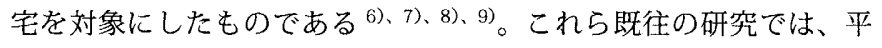
面や立・断面の構成におけるモデュール 7)、8)、架構や素材の組み合 わせによる空間の構成形式 ${ }^{6)}$ 、構成部材の配置 ${ }^{9}$ 、などを分析の手 段として、構成分析の方法自体の提案 ${ }^{9)}$ や設計者個人にみられる架 構の特徴や傾向を設計者自身の言説や社会的な背景などと結び付け た考察 ${ }^{6) 、 7) 、 8) ~ な と ゙ か ゙ タ ら れ る 。 ~}$

本研究は、架構による空間構成や形態構成の類型を問題にするの ではなく、複数の住宅作品を対象とし、架構によるモデュールを柱 や梁などの架構各部の寸法や材質から捉え、寸法の相互関係にみい だされるモデュールによる表現の特徴を明らかにすることを目的と するものであり、そのような方法・視点から実体としての建築にお ける空間のスケールを捉える研究はこれまでにみられない。

\footnotetext{
* 東海大学第二工学部建築デザイン学科、研修員・工修 Staff, Dept. of Architectural Design, School of Engineering II, Tokai Univ., M. Eng. 


\section{2. 研究資料の選定と研究方法}

本研究では、まず、架構の形状や柱の配列より、門型などの単一 フレームが一方向に均等に反復するものを「門型」形式、柱がグリッ ト状に配置されたものを「グリッド型」形式として分類した。次に、 それぞれの架構形式について、架構寸法、すなわち部材各部の寸法 やスパンおよびスパン数などを検討することにより、それぞれの形 式における寸法の傾向と関係を導く。さらにこれらを重ね合わせる ことで、架構によってつくられる $1 \times 1$ スパンの空間にみられる性 格を検討し、架構によるモデュールの特徴を考祭する。

資料となる独立住宅作品の選定にあたっては、現代建築ジャーナ リズムのなかで代表的なものであると思われる「新建築住宅特集」 誌及び「新建築」誌（1990 年 1 月号から 2002 年 12 月号）に「JA」 誌（1991 年 No.1 から 2002 年 No.47）を補足した 13 年間に揭載 された独立住宅作品の中で、写真および図面より柱・梁などの線材 により構成される架構が門型あるいはグリッド状に等間隔に配列さ れ、それらの架構が建物内部あるいは外部において露出し、連続的 に配置されることで表現手段となっている全 118 作品(門型 83 作品、 グリッド型 35 作品） ${ }^{11)}$ を分析の対象としている。

\section{3. 門型架構におけるモデュール}

門型架構におけるモデュールは、図-1 の分析例のように、架構 の形 (以下架構形状)、構造形式 ${ }^{10}$ )、梁行きのスパン (以下スパン $\mathrm{x}$ )、桁行きのスパン（以下スパン y) とそのスパン数（以下スパン数 $\mathrm{Ny}$ )、主室（もっとも床面積が大きい部屋）における床から梁上（梁 が露出していない場合は天井）までの高さ方向に揸りる寸法（以下 高さ)、柱・梁などの架構の材質・形状により捉えられる。

\section{3-1 架構形状と架構材質の関係}

門型架構における架構の形状と材質による分類および階数別の内 訳を表-1に示した。架構形状は、室内に扔いて架構の一部か全てが 露出しているか、梁が曲線か直線か、直線ならば水平か GLに対して 傾いているかを分類の基準としており、門型架構を持つ全資料につ いて分析した結果、曲線によるヴォールト型（、以下括弧内は対 応する記号)、GLに詨して傾いた直線よる片流れ型 ( ) 及び切妻型 (へ)、水平な直線よるフラット型（円）、梁と柱の一方が露出し、他 方が壁による L 型（П)、柱のみが露出しているI型（间）６つに 分類された。架構の形状と材質についてみるとフラット型のものが 資料の過半を占め、中でも鋼材の大半はこの形状で占められていた。 木材については、フラット型、切り妻型、片流れ型といった様々な 形状がみられた。また、階数については、2 階建てが過半を占め、木材、 鋼材ともに最も多くみられたが、木材では平屋が、鋼材では 3 階建 て以上が 2 階建てに次いで多くみられた。

\section{3-2. スパン $\mathrm{x} \cdot \mathrm{y}$ およびスパン数 $\mathrm{Ny}$ との関係}

門型架構を表現する住宅作品においては、スパンやスパン数の設 定がその表現に染く関わっていると考えられる。そこで、梁行き方 向と桁行き方向のスパンの相互関係をみるために、横軸をスパン $\mathrm{x} 、$ 縦軸をスパンyとするグラフを作成した（図 -2)。まず、スパンy についてみると、尺モデュールである 450、900、1800mm といっ た寸法に資料が集中しており、その大半が木材で占められていた。 $1500 \sim 2700 \mathrm{~mm}$ の範囲では木材および鋼材が混在し、これ以上 の寸法では鋼材が多くなっていた。また、1000〜 1500mm の間と

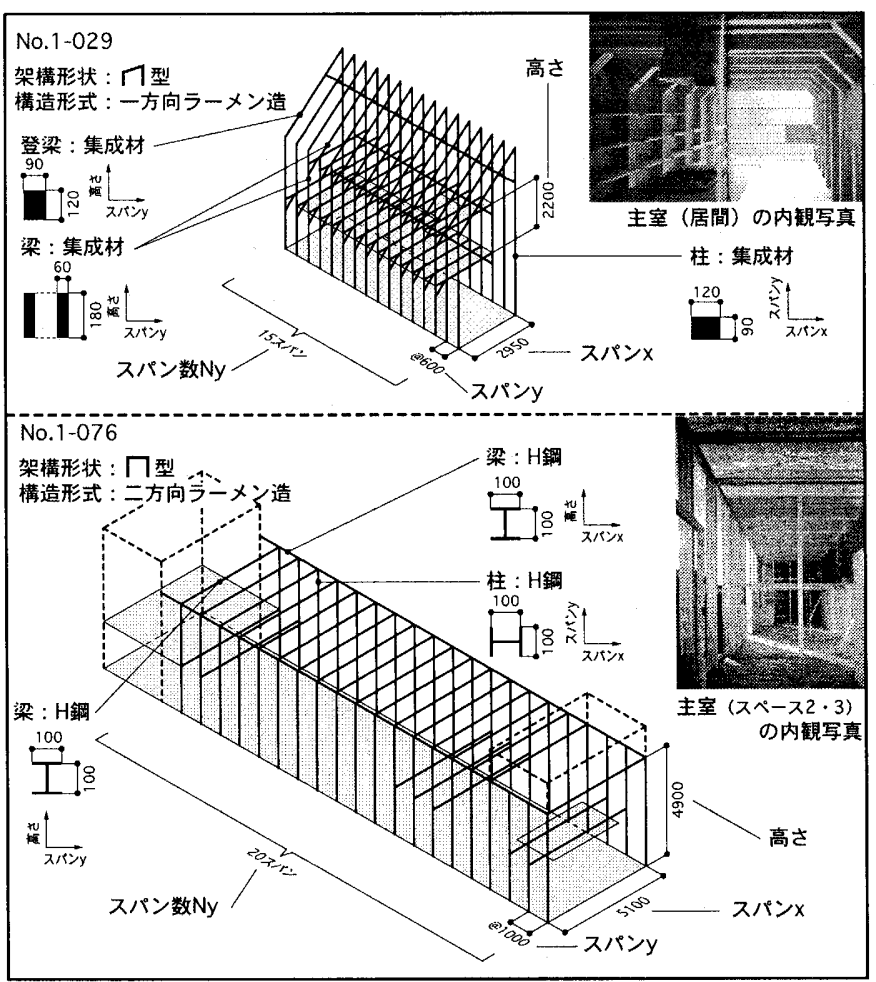

図-1 門型架構における分析例

表-1 門型架構における架構の形状と材質の関係

\begin{tabular}{|c|c|c|c|c|c|c|c|c|}
\hline 材留 & $\square$ & $\prod$ & $\bigcap$ & $\bigcap$ & $\vdots$ & \lceil\rceil & その他 & 合計 \\
\hline 木材 & $\begin{array}{c}17 \\
1 F / 3 \\
3 F / 3\end{array}$ & $\begin{array}{c}10 \\
11 F / 2 \quad 2 F / 8 \\
\end{array}$ & $\begin{array}{c}9 \\
1 F / 3 \\
3 F / 1 \\
3 F / 5\end{array}$ & $\begin{array}{c}4 \\
1 F / 2 \\
2 F / 2\end{array}$ & $\begin{array}{c}2 \\
1 F / 1 \\
2 F / 1\end{array}$ & $\begin{array}{l}1 \\
2 F / 1\end{array}$ & $\begin{array}{c}3 \\
1 F / 2 \quad 2 F / 1\end{array}$ & 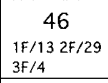 \\
\hline 鋼材 & $\begin{array}{c}26 \\
1 F / 1 \\
3 F / 7 \text { 他/15 } \\
3 F / 3\end{array}$ & & $\begin{array}{c}3 \\
2 F / 2 \\
3 F / 1\end{array}$ & $\int_{3 F / 1}^{2} 2 F / 1$ & $\begin{array}{l}1 \\
2 F / 1\end{array}$ & & $\begin{array}{l}1 \\
\text { 地/1 }\end{array}$ & 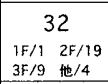 \\
\hline$R C$ & $\begin{array}{l}1 \\
2 F / 1\end{array}$ & & & & & 1 & & $\begin{array}{c}2 \\
1 F / 1 \quad 2 F / 1\end{array}$ \\
\hline その他 & & & $\begin{array}{l}1 \\
2 F / 1\end{array}$ & & & $\begin{array}{l}1 \\
2 \mathrm{~F} / 1\end{array}$ & & $\begin{array}{l}2 \\
2 F / 2\end{array}$ \\
\hline 合計 & $\begin{array}{c}44 \\
1 F / 42 F / 27 \\
3 F / 10 \text { 他/3 }\end{array}$ & $\begin{array}{c}10 \\
1 \mathrm{~F} / 2 \quad 2 \mathrm{~F} / \mathrm{s}\end{array}$ & $\begin{array}{c}13 \\
1 F / 32 F / 8 \\
3 F / 2\end{array}$ & $\begin{array}{c}6 \\
1 F / 2 \\
3 F / 1 \\
2 F / 3\end{array}$ & $\begin{array}{c}3 \\
1 F / 1 \quad 2 F / 2\end{array}$ & $\begin{array}{c}3 \\
1 F / 1 \\
2 F / 2\end{array}$ & \begin{tabular}{|c|}
4 \\
$1 F / 2$ \\
$1 F / 2$ \\
他/1/
\end{tabular} & $\begin{array}{c}83 \\
1 F / 152 F / 52 \\
3 F / 13 \text { 他/4 }\end{array}$ \\
\hline
\end{tabular}

スパンy

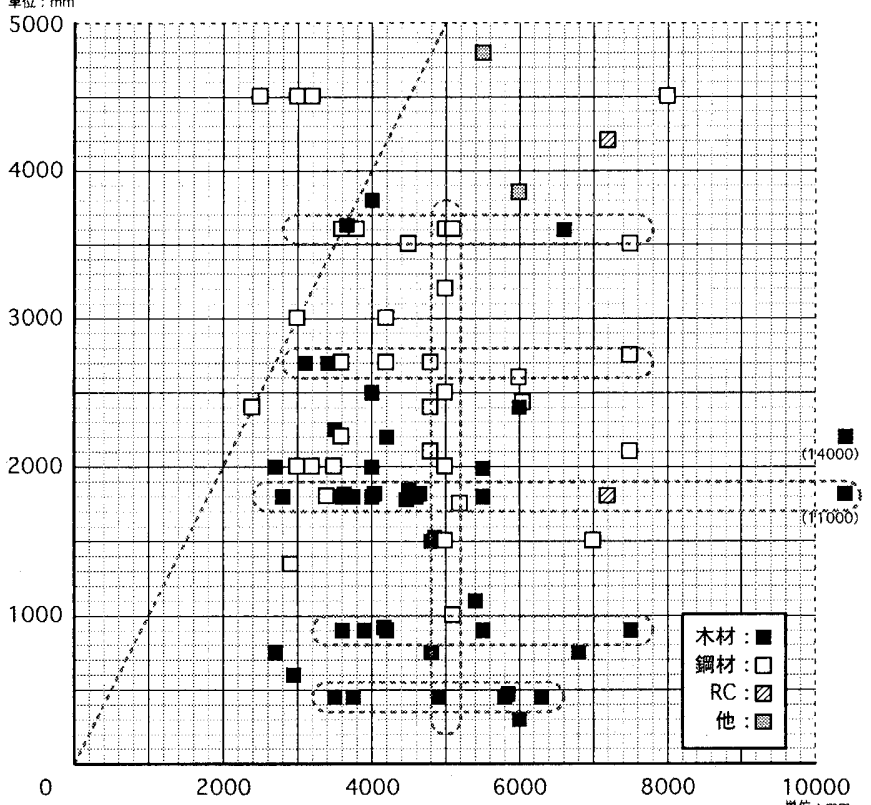

図-2 門型架構におけるスパン $x \cdot y$ の関係 
3000〜3500mm の間には資料がほとんどみられなかった。

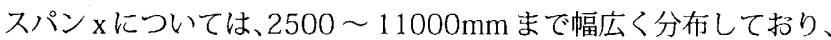
一定の寸法に集中する傾向はみられなかったが、5000mm 前後に䤱 材が比較的集中していた。

次に、桁行き方向のスパンとそのスパン数の相互関係をみるため に、横軸をスパンy、縦軸をスパン数 Ny とするグラフを作成した（図 -3)。全資料は全長が $20 \mathrm{~m}$ をあらわすライン（スパン $\mathrm{y} \times$ スパン数 $\mathrm{Ny}=20 \mathrm{~m} ）$ に沿って集中しておりり、全長が近似している門型架構の スパン数にばらつきがあることがわかった。

架構の材質に着目すると、木材はスパン y が $1800 \mathrm{~mm}$ 以下で 10 ２0スパンの間に集中しているのに対し、鋼材はスパン y が $2000 \mathrm{~mm}$ 以上で $5 \sim 10$ スパンの間のものが多くみられた。中には RC でスパン $\mathrm{y}$ が $1800 \mathrm{~mm}$ 、スパン数 Ny が 20 スパンというかなり 特殊な例もみられたが、これはスパン $\mathrm{x}$ 、すなわち梁行きのスパンの 大きさが $7200 \mathrm{~mm}$ あることや、通常の部材断面の逸脱を狙った設計 者の意図などがあるためである。これらのことより、門型架構を表 現手段とする住宅作品における架構の材質は、梁行きのスパンの大 きさにあまり関係なく木材、鋼材が混在していることから、桁行き のスパンの大きさがその材質の決定に関係しているといえる。

\section{4. グリッド型架構におけるモデュール}

グリッド型架構におけるモデュールは、図 -4 の分析例のように門 型架構の場合と同様、架構形状、構造形式、スパンおよびスパン数、 高さ、架構の材質・形状抽よび断面寸法により捉えることができるが、 1 方向に反復する門型架構とは異なり、グリッド状に反復しているた め、スパン数の少ない方を梁行き（x方向）、多い方を析行き（y 方向） とすることで、スパン数 $\mathrm{Nx} \cdot \mathrm{Ny}$ 、スパン $\mathrm{x} \cdot \mathrm{y}$ として捉えられる。

\section{4-1架構の形状と材質の関係}

グリッド型架構における架構の形状と材質による分類および階数 別の内訳を表 - 2 に示した。架構形状は、室内に扔ける架構の露出度 合いや、梁の形状や傾きなどを門型架構の場合と同様に分類の基準 としており、グリッド型架構を持つ全資料について分析した結果、 フラット型 (口)、片流れ型 (へ)、切妻型 (ヘ)、ヴォールト型 ( )、L 型 (D)、I 型 (门)、さらにこれらの組み合わせによるフラット

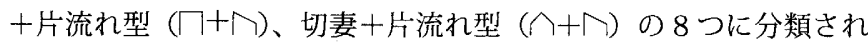
た。架構の形状と材質についてみていくと、フラット型が資料の半 数を占め、その大半が鋼材であった。片流れ型は、その全てが木材で、 片流れとの複合型であるフラット十片流れ型、切り妻十片流れ型な どを合わせると、フラット型と片流れ型が資料の大半を占め、門型 架構と較べ架構形状に偏りがみられた。階数については、2 階建てが 大半を占めており、架構の形状や材質との関係はみられなかった。

\section{4-2 スパン $x \cdot y$ およびスパン数 $\mathrm{Nx} \cdot \mathrm{Ny}$ との関係}

グリッド型架構を表現する住宅作品では、1 グリッドの大きさ、す なわち $1 \times 1$ スパンにおけるスパンの大きさや $\mathrm{n} \times \mathrm{n}$ スパンといっ たグリッド数の設定がその表現に梁く関わっていると考えられる。 そこで、梁行きと桁行きのスパンの相互関係をみるために、横軸を スパン $\mathrm{x} 、$ 縦軸をスパン $\mathrm{y}$ とするグラフを作成した（図 -5)。この図 より、スパン $\mathrm{x} \cdot \mathrm{y}$ は同一 $(\mathrm{x}=\mathrm{y})$ である、いわゆる正方形グリッド をもつものが圧倒的に多いことがわかった。1 グリッドの大きさにつ いてみると、1800～4800mm まで幅広い範囲でみられたが、その

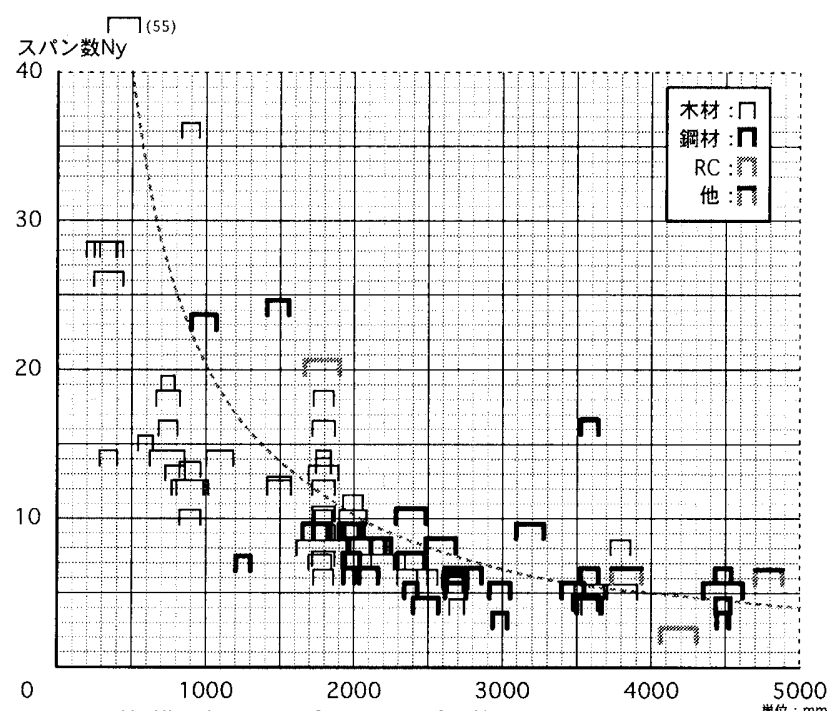

図-3 門型架構におけるスパンyとスパン数 Ny の関係

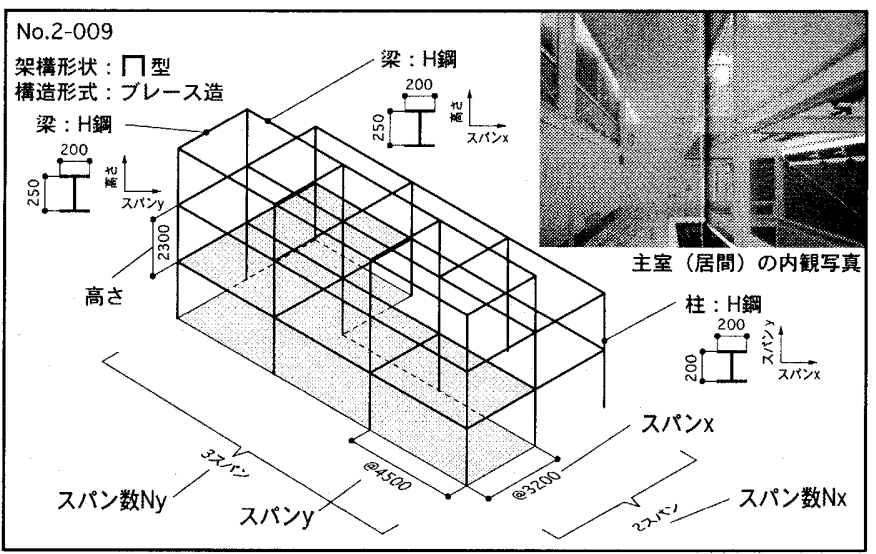

図-4 グリッド型における分析例

表-2 グリッド型における架構の形状と材質の関係

\begin{tabular}{|c|c|c|c|c|c|c|c|c|c|}
\hline 材壮 & & & & & & & $\begin{array}{l}\prod_{+} \\
\Pi^{2}\end{array}$ & $\bigcap_{+}^{+}$ & 合計 \\
\hline 木材 & $3_{3 F / 1}^{3}$ & ${ }_{3 F / 1}{ }_{2 E / 7}$ & & ${ }_{1 F / 1}^{1}$ & 1 & ${ }_{11 / 2} 2$ & $1_{2 F / 1}$ & ${ }_{1 F / 4} 4$ & $\begin{array}{c}20 \\
1 F / 4 \\
3 F / 3\end{array}$ \\
\hline 鋼材 & 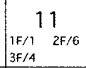 & & ${ }_{3 F / 1}^{1}$ & & $1_{2 F / 1}$ & & & & 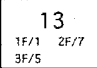 \\
\hline $\mathrm{RC}$ & $1_{2 F / 1}$ & & & & & & & & $1_{2 F / 1}$ \\
\hline その他 & $1_{2 F / 1}$ & & & & & & & & $1_{2 F / 1}$ \\
\hline 合計 & $\begin{array}{c}17 \\
1 F / 1 \\
3 F / 5 \\
2 F / 10\end{array}$ & $\begin{array}{c}8 \\
2 F / 7 \\
3 F / 1\end{array}$ & $\begin{array}{r}1 \\
3 F / 1 \\
\end{array}$ & ${ }_{1 F / 1}^{1}$ & ${ }_{3 F / 7}^{2}$ & ${ }_{1 F / 2}^{2}$ & 1 & $\begin{array}{c}4 \\
1 F / 1 \\
1 F / 3\end{array}$ & $\begin{array}{c}35 \\
17 / 5 \\
3 F / 8 \\
3 F / 8\end{array}$ \\
\hline
\end{tabular}

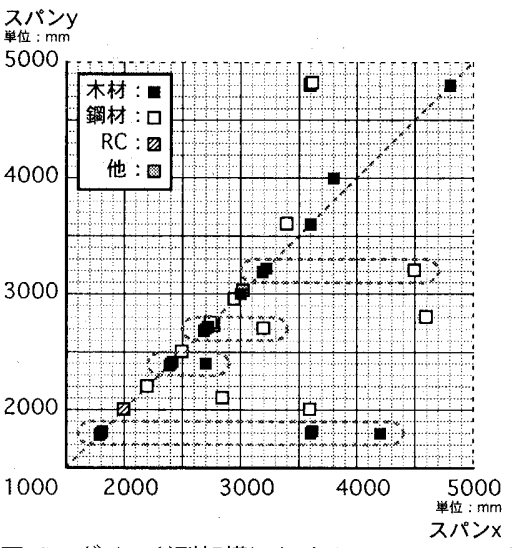

図-5 グリッド型架構における スパン $\mathrm{x} \cdot \mathrm{y}$ の関係

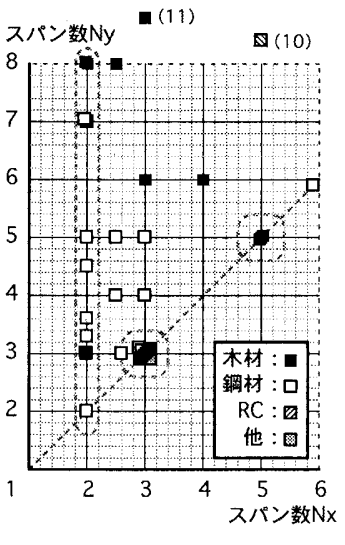

図 -6 グリッド型架構における スパン数 Nx・Nyの関係 
中でも 1800、2400、2700、3150mm といった尺モデュールに集 中しており、それらの大半は木材であった。鋼材については、メーター モデュールのものや、長方形グリッドなどに多くみられた。

次にグリッド数、すなわち杵行き方向と梁行き方向のスパン数の 相互関係をみるために、横軸をスパン数 $\mathrm{Nx}$ 、縦軸をスパン数 $\mathrm{Ny}$ と するグラフを作成した（図 -6)。スパン数に関しても $\mathrm{Nx}$ ・ Ny ともに 同スパンである $3 \times 3$ スパン $(\mathrm{Nx}=3 \times \mathrm{Ny}=3)$ と $5 \times 5$ スパンのも のが資料の過半を占め、その中でも $3 \times 3$ スパンのものは特に多く みられた。また、これら同スパン数のものは、その全てが正方形グ リッドであるといった特徴があった。この他の特徴として、スパン 数 $\mathrm{Nx}$ ・ Ny が異なるものは $2 \sim 3 \times \mathrm{n}$ スパンに集中し、特に $2 \times \mathrm{n}$ スパンのものが多くみられた。

\section{5. 架構による単位空間}

前章、前々章では、架構によるモデュールについて、門型・グリッ ド型といった架構形式別に、架構形状や架構寸法を検証した。住宅 作品における架構によるモデュールは、これらの寸法に柱や梁など の架構部材の断面形状や高さなどの大きさが深く関係していると考 えられる。そこで本章では、3 章、4 章から得られた、スパン $\mathrm{x} \cdot \mathrm{y}$ による $1 \times 1$ スパンの空間（以下単位空間）に柱の断面形状や高さ を重ね、架構による単位空間の性格を検討する。

\section{5-1. 柱の断面形状と単位空間}

図 7 は、3 章における門型架構および、4 章におけるグリッド型架 構のスパン $\mathrm{x} ・ \mathrm{y}$ より得られた単位铝間の大きさにそれらの柱の材質 と断面形状および構造形式を重ねて示したもので、さらに柱の断面 形状についてもグラフの縮尺に合わせている。 スパンyについてみると、450、900、1800、2700、3600mm といった尺モデェールのものが多かった。柱の断面形状に着目する と、900mm 前後やそれ以下の寸法では、その大半がッーバイ材や集 成材などの扁平木材を使用した門型架構となっていた。これら扁平 木材を使用した門型架構には、y 方向の端部に大開口をとるために $\mathrm{x}$ 方向ラーメン造かつy 方向ブレース造とする一方向ラーメン造 $(\mathrm{R}+\mathrm{B})$ やSE 構法などにみられる接合部に特殊な金物を用いた半剛節ラーメ ン造（RB）などの構造形式を用いるものが比較的多くみられた。扁 平木材を使用するものは、1800 $\mathrm{mm}$ を境にあまりみられなくなり、 $1800 \mathrm{~mm}$ 前後では $100 \sim 120 \mathrm{~mm}$ 角の木材を使用したブレース（筋 交）造（B）がもっとも多くみられた。中には、一室による空間構成 や開口部にブレ一スなどの斜材が入ることをさけるために不足する $\mathrm{x}$ 方向の水平荷重を補うため、断面寸法の大きい扁平木材を使用する ブレース造もみられた。 $2700 \mathrm{~mm}$ 前後では $120 \sim 150 \mathrm{~mm}$ 角の木材 が比較的多く、それらの大半はブレース造で正方形の単位空間に集 中していた。単位空間が長方形になると $150 \mathrm{~mm}$ 前後の大きさの丸 型や角型、 $\mathrm{H}$ 型など様々な断面形状の鋼材が多くみられ、そのほと んどが $\mathrm{x} \cdot \mathrm{y}$ の両方向をラーメン造とする二方向ラーメン造（R）と なっていた。3600 mm 以上になると鋼材が大半を占め、柱の断面寸 法を小さくするために一方向ラーメン造やブレース造などを用いる ものや、二方向ラーメン造でも $\mathrm{RC}$ 造の壁に水平荷重の一部を負担さ せるものなどがみられた。その一方で、柱の断面寸法を大きくする ことでブレースの数を減らすといった、まったく逆の方法をとるも のもみられた。尺モデュール以外の寸法では、2000、3000 mm といっ たメーターモデュールに集中するものがみられ、木材は断面の大き いものが多く、2500mm 以下では $150 \mathrm{~mm}$ 角程度の H 型の鋼材を使

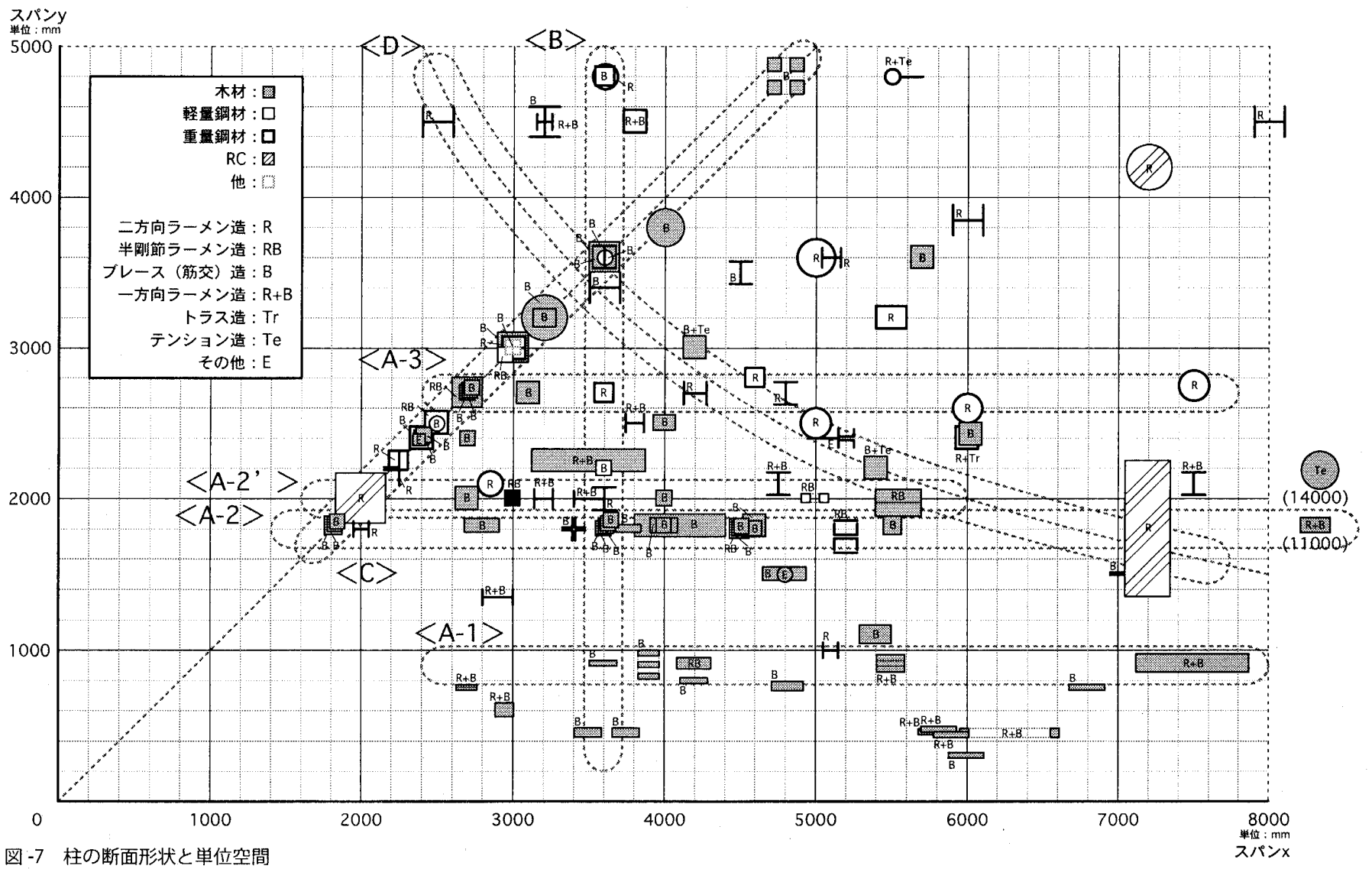


用した一方向ラーメン造が比較的多くみられた。

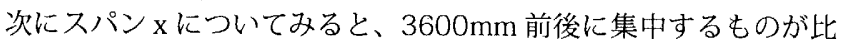
較的多く、その大半は、スパン $\mathrm{y}$ がスパン $\mathrm{x}$ の半分の大きさである $1800 \mathrm{~mm}$ と、スパン $\mathrm{x}$ と同一の $3600 \mathrm{~mm}$ に集中していた。スパン $\mathrm{y}$ が $1800 \mathrm{~mm}$ 付近の柱の断面形状ついては、その全てが $100 \mathrm{~mm}$ 角の 木材を使用した軸組造であった。

スパン $\mathrm{x} \cdot \mathrm{y}$ につてみると、 $\mathrm{x} \cdot \mathrm{y}$ ともに同一である正方形平面の 単位空間に集中しており、それらの柱の材質については木材、鋼材、 $\mathrm{RC}$ など様々なものがみられたが、構造形式はブレース造のものが、 柱の断面形状については正方形のものが大半を占めていた。この他 には、単位空間の面積が $11 \sim 13$ mを表すライン (スパン $\mathrm{x} \times$ スパ ン $\left.\mathrm{y}=11 \sim 13 \mathrm{~m}^{2}\right)$ に沿って集中するものがみられた。このラインに 沿うものには、鋼材が比較的多く、150mm 程度の角型や丸型、 $\mathrm{H}$ 型 を使用した二方向ラーメン造が大半を占めていた。また、木材を使 用したものには梁にテンション造（B+Te）などの構造形式を使用す る特殊なものがみられた。

\section{5-2. 特定のスパンy からみた架構による単位空間}

ここでは図-7 より得られた、特定のスパン $\mathrm{y} に お け る$ 単位空間（図 7 中< A-1 〜 A-3 >グループ）の中で、門型・グリッド型架構を通 してもっとも多く見られたフラット型の架構形状をもつ資料の高さ を分析し、それらを空間ヴォリュームとして抽出したものを図-8に 示した。以下にその特徵を述べる。

< A-1 >は、スパン y が $900 \mathrm{~mm}$ 前後の単位空間である。スパン $\mathrm{x}$ に対する高さ、すなわちスパン $\mathrm{x}$ 側の断面（以下断面）のプロポー ションについてみていくと、打およそ 1:0.5〜0.6 (スパン $\mathrm{x}$ 高さ、 以下同）の比であることがわかる。

< A-2 >は、スパン y が $1800 \mathrm{~mm}$ 前後の単位空間である。スパン $\mathrm{x}$ の大小にかかわらず、高さは $2600 \mathrm{~mm}$ 前後 $(2500 \sim 2700 \mathrm{~mm}$ )
とほぼ一定の大きさで、く A-1 >とは異なり、特定のプロポーショ ンによらないことがわかる。

$<\mathrm{A}-2^{\prime}>$ は、スパン y が $2000 \mathrm{~m}$ の単位空間である。<A-1 >と 同様に断面にはある一定のプロポーションが見られるがく A-1 >と は異なり、より正方形に近いプロポーション $(1: 0.8 〜 1)$ であるこ とがわかる。

< A-3 >は、スパン y が $2700 \mathrm{~mm}$ 前後の単位空間である。< A-2 $>$ と同様、スパン xの大小にかかわらず、高さは $2600 \mathrm{~mm}$ 前後でほ ぼ一定の大きさであることがわかる。

\section{5-3. 特定の条件からみた単位空間}

ここでは図 -7 より得られた、スパン $\mathrm{x}$ や平面形状、面積などの特

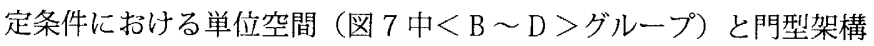
に比較的多くみられた切妻型の架構形状における単位空間について、 前項と同様に高さを分析し、空間ボリュームとして抽出したものを 図 -9に示した。

< B >は、スパン x が 3600mm 前後の単位空間である。高さは、 一部の例外を除き $2200 \sim 3600 \mathrm{~mm}$ と比較的幅広く分布して抢り、 <B > における単位空間に共通する傾向はみられない。

$<\mathrm{C}>$ は、スパン $\mathrm{x}$ とスパン $\mathrm{y}$ が同じ大きさの正方形平面におけ る単位空間である。高さは $2200 ２ 800 \mathrm{~mm}$ の間に比較的集中して いるが、断面に一定のプロポーションがみられ、その比はほぼ 1:1（正 方形）になっている。すなわち（C>に执いてはスパン $\mathrm{x} ・ \mathrm{y}$ 、高さ ともに同じ大きさである立方体の単位空間になることがわかる。

$<\mathrm{D}>$ は、平面の面積が $11 \sim 13 \mathrm{~m}$ (スパン $\mathrm{x} \times$ スパン $\mathrm{y}=11$ $13 \mathrm{~m}$ ）の単位空間である。断面についてみると、ほぼ正方形に近い プロポーション（1:0.9～1）がみられる。<D>においてはスパン $\mathrm{x}$ に対してスパン $\mathrm{y}$ は反比例し高さは比例するため、スパン $\mathrm{x}$ が小さ くなると、高さが小さくスパン y が大きい細長い単位空間に、スパ

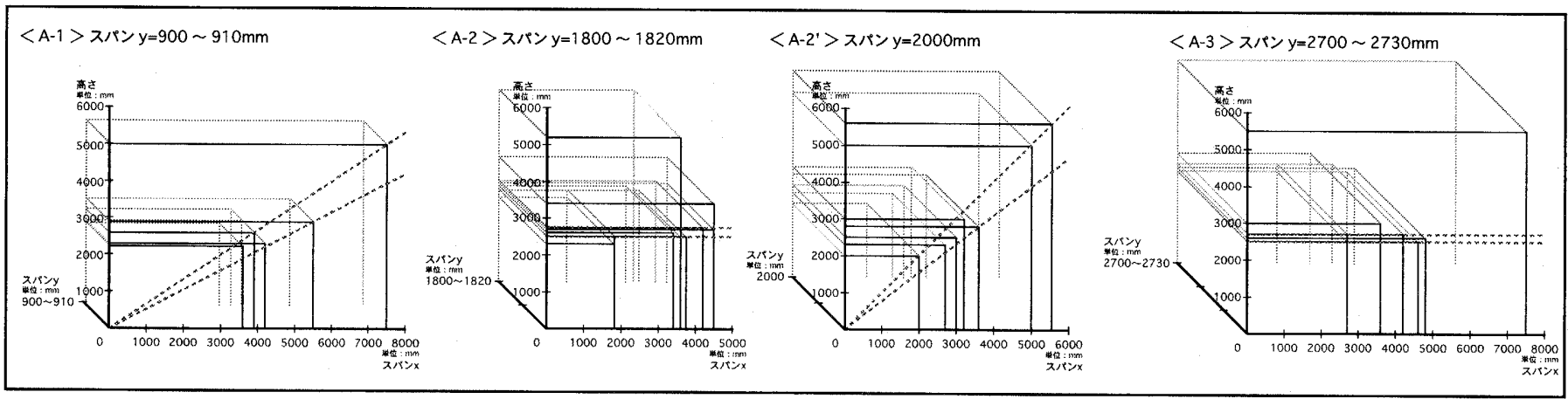

図-8＼cjkstart特定のスパンyからみた架構による単位空間

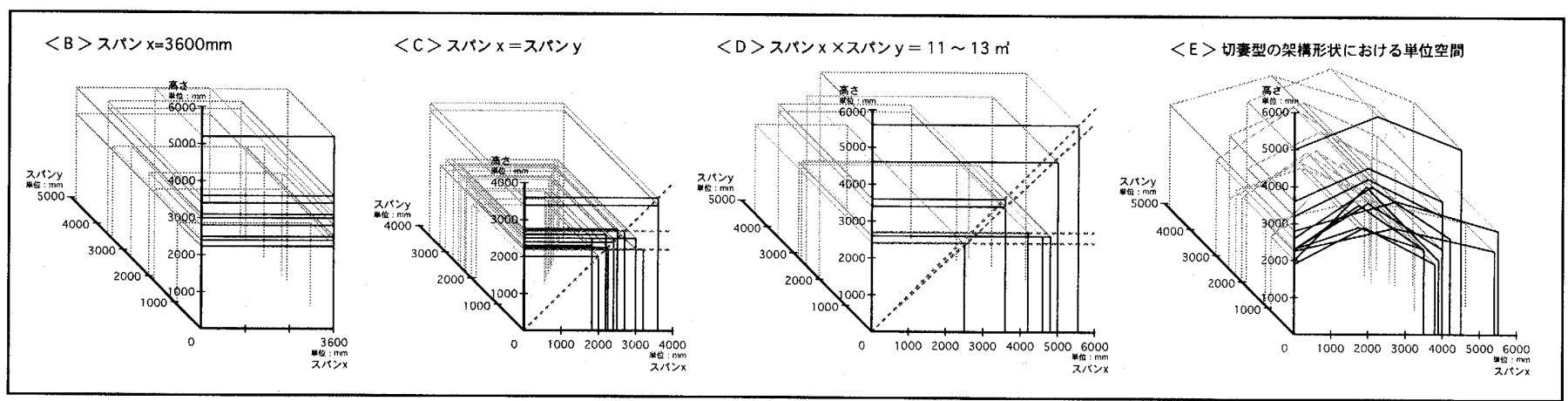

図-9 特定の条件からみた架構による単位空間 


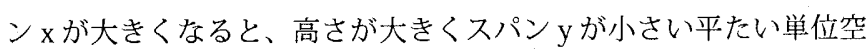
間になることがわかる。

< E >は、門型架構で切妻型の架構形状の単位空間である。ス パン $\mathrm{y}$ は $910 \sim 4800 \mathrm{~mm}$ と幅広く分布しているが、スパン $\mathrm{x}$ は $4000 \mathrm{~mm}$ 前後に比較的集中している。登梁の勾配についてみていく と、スパン xが $5000 \mathrm{~mm}$ 以下ではその大半が 1:0.4〜0.6 といった 一般に 4 寸〜 6 寸勾配と呼ばれる勾配になり、スパン $\mathrm{x}$ が $5000 \mathrm{~mm}$ 以上になると 1:0.3(3寸勾配)と比較的緩い勾配になることがわかる。

\section{6. 結}

本研究では、架構によるモデュールについて、まずそれらの架構 の形状と材質の組み合わせから分類を行い、次にスパンやスパン数 などの架構寸法を検討することから、柱の配列が異なる 2 つ形式 におけるそれぞれの傾向を明らかにした。

さらに上記の 2 つの異なる形式から得られた $1 \times 1$ スパンの単位 空間にその柱の材質と断面形状、構造形式を重ねて検討することに より、その空間の大きさと柱の材質や断面形状、構造形式との間に いくつかの傾向をみいだした。また、こうした単位空間に高さを加え、 立体空間として抽出したものを検討することにより、桁行き方向の スパンに対する高さや、梁行き方向のスパンと高さによる断面のプ ロポーション、梁行き方向のスパンに対する梁の勾配などの傾向を 明らかにした。

以上で得られた結果は、現代日本の独立住宅作品における架構に よるモデュールが、ある一定の寸法やプロポーションに沿っている ことを示しており、架構によるモデュールの空間スケールや形態的 特徴の一端が架構各部の寸法関係にもとづいていることが明らかと なった。

\section{本論文に関する既発表論文}

1）竹内宏俊、浅沼真一、岩网竜夫：独立住宅にみられるグリッド型架構のモデュールについ て一現代建築のくスケール>に関する研究 その $13 、$ 日本建築学会大会学術講演梗概集 F-2、p.p643 -644、2004 年

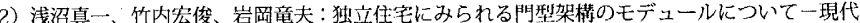
建築のくスケール〉に関する研究 その 14、日本建築学会大会学術講演梗概集 F-2、p.p645 ～646、2004 年:

\section{参考文献及び註}

1)「架構」については「複数の部材で構成された骨組。部材の組み方や形状により、ラーメン トラスあるいはアーチなどに分かれる。(建築学用語辞典筑二版、日本建筑学会、p.104)」や材 を結合して作った構造物（広辞苑第五版、岩波書店、p.486)」といった定義がされている。 本研究では、建物の主要構造を構成している柱や梁などの骨組みを架構と呼ぶ。

2）ケネス・フランプトン著、松畑強／山本想太郎訳：テクトニック・カルチャーー19-20 中田 紀建築の構法の詩学、T O T O 出版、2002 年、pp17、によるとテクトニック（結構）と いう言葉は、大Iや建設者を意味するギリシア語のテクトン（tekton）という言葉を語源に 持ち、それがやがてホメロス（古代ギリシア最古の叙事詩人）の缜には建設の技芸を、そし

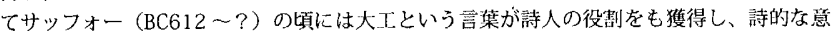
味を持つにいたり、最終的には楝梁やアルキテクトン（architekton）に行き着きことになり、 技術的なものから美的なものへと変容していくと述べられている。

3）「モブュール」については「(1)建築各部を簡単な比率で示せる寸法単位。ギリシャ建築、ロー マ建築で忙柱身下部の径を基準にすることが多い。(2)建筷の設計において基準として用いる 単位寸法、または数列化した寸法群。(3)建築を構成する箱形のエニット。工場生産されたモ デュールは現場に輸送され、積み重ねられて住宅などの建築になる。(4)回路系など一組の装 置の構成単位。（建築学用語辞典第二版、日本建築学会、p.729）」などと定義されている。 本研究では均等間隔に反復する柱や梁などの架構により構成される空間単位をモデュールと 呼ぶ。

4）塚本由晴、奥矢惠、坂本一成：住宅作品における架構表現による構成単位の分節一住宅建築 の構成形式に関する研究、日本建築学会計画系論文集、No:480、pp113－121、1996.02

5）中井邦夫，妹尾慎吾，坂本一成，垷代建築作品における架構と空間構成一外形ヴオりューム の分䬣による建築の構成形式に関する研究 その 3、日本建築学会計画系諞文集、No.551、 pp149 155、2002.01

6）那須 聖，八木幸二，大鳥 ケン 正：RM シンドラーの住宅に扔るる機能空間の構成からみ た素材と架構の表現一南カリフォルニアに扔ける近代住宅の空間構成に関する研究、日本建 築学会計画系論文集、No.517、pp313～319、1999.03
7）末包伸吾: ルドルフ・シンドラーの住宅建築における空間構成材とモデュールによる空間構 成法、日本建築学会計画系論文集、No.494、pp261 267、1997.04

8）末包伸吾: リチャード・ノイトラの住宅作品における空間構成材とモデュールによる空間構 成法、日本建築学会計画系論文集、No.521、pp277〜319、1999.07

9）堀江亭：日本の伝統的民家の架構配置に関する分析術語定義一木造軸組工法の空間構成に 閉する研究 その1、日本建築学会計画系論文集、No.501、pp117～124、1997.11

10）「構造形式」の区分は、材料の種類、構法、施工方式などにより分類することができるが、 本研究ではラーメン造やブレース（筋交）造といった耐力要素を分類の基準とした。

11）付表 資料リスト

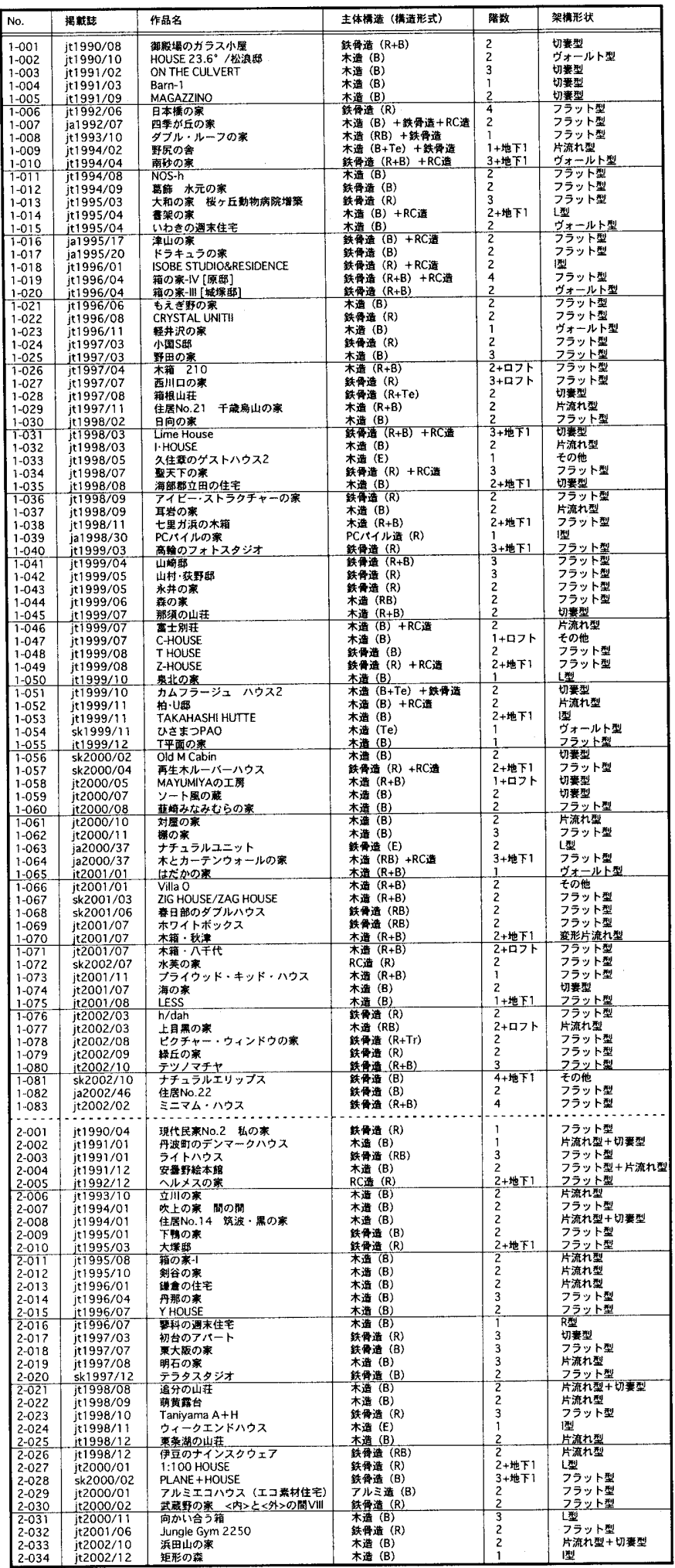

※ 1 揭載誌名の記号はそれぞれ、sk：「新建築小 jt：「新建築住宅特集」 ja：「ja」を示す ※ 2 構造形式の記号はそれぞれ、R:「二方向ラーメン造」RB:「半剛節ラーメン造」、B:「ブレー 又 (筋交) 造小 R+B：「一方向ラーメン造かつ他方向ブレース造」、 $\mathrm{Tr}$ ：「トラス造」、Te :「テ ンション造」 $\mathrm{E}:$ 「ての他」を示す 